\title{
ANALISIS KUALITAS TANAH PADA LAHAN TEGALAN BERPASIR DI DAS MIKRO SUPITURUNG, KABUPATEN KEDIRI, JAWA TIMUR
}

\section{Analysis of Soil Quality on Sandy Dry Lands in the Supiturung Micro Watersheds, Kediri Regency, East Java}

\author{
Mochamad Fikri Kurniawan*, Mochtar Lutfi Rayes, Christanti Agustina \\ Jurusan Tanah Fakultas Pertanian Universitas Brawijaya, Jl. Veteran No. 1, Malang 65145 \\ *Penulis korespondensi: mochamadfk@gmail.com
}

\begin{abstract}
Soil quality is the ability of soil that plays a role in maintaining plant productivity, preserving and maintaining water availability and supporting human activities. Soil quality assessment is measured based on indicators that describe important soil processes based on the physical, chemical and biological properties of the soil. The level of soil quality in a plot of land is assessed based on the soil quality index. This research was conducted from August to December 2020 in the Supiturung Micro Watershed, Kediri Regency, East Java using a graphical survey method based on the Land Map Unit. Soil samples were taken at a depth of $0-20 \mathrm{~cm}$ at each observation point (20 points) for analysis in the laboratory. Soil quality indicators are determined based on key soil properties with the Minimum Data Set (MDS) method, with soil quality indicators from soil physical properties including texture, bulk density, porosity and soil chemical properties including $\mathrm{pH}$, available- $\mathrm{P}$, exchangeable- $\mathrm{K}$, total$\mathrm{N}$, organic-C. Soil quality index was calculated by weighting soil quality indicators with criteria which divided into 5 classes, i.e. (i) very low class $(0.00-0.19)$, (ii) low (0.20-0.39), (iii) moderate (0.40-0.59), (iv) good (0.60-0.79) and (v) very good (0.80-1.00). The results showed that the soil in land unit 2 had different limiting factor values on the percentage of sand and dust from the soil texture, the total-N content of the soil and the organic-C content of the soil which caused differences in soil quality. There are two indicators of soil quality, namely the percentage of dust from the soil texture and the total $\mathrm{N}$ content of the soil which has the most influence on the soil quality index.
\end{abstract}

Keywords : analysis, indicators, minimum data set (MDS), sandy dry lands, soil quality index

\section{Pendahuluan}

Kualitas tanah merupakan kemampuan suatu tanah yang berperan dalam mempertahankan produktivitas tanaman, menjaga dan mempertahankan ketersediaan air serta menunjang aktivitas manusia (Minarsih dan Hanudin, 2020). Menurut Padmawati et al. (2017), penilaian kualitas tanah diukur berdasarkan indikator perubahan fungsi tanah sebagai tanggapan dari pengelolaan tanah. Beberapa indikator yang dinilai dalam proses evaluasi kualitas tanah yaitu indikator-indikator yang menggambarkan proses penting tanah berdasarkan dari sifat fisika, kimia dan biologi tanah. Tingkat kualitas tanah pada suatu bidang lahan dinilai berdasarkan indeks kualitas tanah (IKT) (Partoyo, 2005). Penilaian kualitas tanah dapat berfungsi sebagai alat bagi manager pertanian dan bagi pembuat kebijakan lainnya untuk mendapatkan pemahaman yang lebih baik tentang sistem pertanian yang dapat mempengaruhi sumberdaya tanah (Dong et al., 2013). Kualitas tanah yang terjaga akan berpengaruh kepada manusia secara ekonomi dengan penjualan hasil panen, ketahanan tanah terhadap erosi, kesehatan manusia yang terminimalisasi dari pengaruh logam berat (Wander et al., 2002). 


\section{Jurnal Tanah dan Sumberdaya Lahan Vol 8 No 2: 527-537, 2021 \\ e-ISSN:2549-9793, doi: 10.21776/ub.jts1.2021.008.2.23}

DAS Mikro Supiturung, Kabupaten Kediri, Jawa Timur merupakan hamparan bekas aliran lahar yang mempunyai topografi bergelombang dengan kemiringan lereng 0-15\%, berbatu dan berpasir Hal tersebut menyebabkan karakteristik lahan memiliki tekstur tanah dominan berpasir. Dengan kondisi geografis yang seperti itu, sebagian besar masyarakat memanfaatkan lahan sebagai tegalan dengan komoditi utama tebu dan nanas. Luasan penggunaan lahan tegalan mencapai $1.155,25$ ha atau sekitar $60,44 \%$ dari luas total wilayah, dengan penggunaan lahan yang seperti itu untuk proses produksi tanaman maka dapat menyebabkan terjadinya penurunan pada kualitas tanahnya. Sebagai akibat dari penurunan kualitas tanah maka tanah tidak dapat menjalankan fungsinya dengan baik. Sumberdaya yang ada pada suatu lahan harus dikelola dengan baik agar dapat dimanfaatkan secara berkelanjutan. Salah satu pendekatan dalam upaya meningkatkan pengelolaan dan sistem penggunaan lahan di suatu wilayah adalah melalui penilaian kualitas tanah (Rahmanipour et al., 2014).

Tewu et al. (2016) berpendapat bahwa kegiatan budidaya pertanian di atas tanah berpasir terdapat banyak kendala yang berhubungan dengan sifat fisik, kimia dan biologi tanah serta iklim yang tidak sesuai untuk pertumbuhan tanaman, unsur hara yang rendah, sehingga keadaan tersebut tidak mendukung untuk pertumbuhan tanaman. Memperhatikan kendala-kendala yang ada khususnya pada tanah berpasir, maka perlu dilakukan kajian lebih dalam mengenai kualitas tanah pada lahan berpasir di lokasi penelitian sehingga dapat memberikan informasi tentang strategi manajemen lahan yang tepat sesuai dengan tingkat kualitas tanah yang ada. Untuk mempermudah dalam menyampaikan informasi kepada masyarakat dilakukan dengan pembuatan peta sebaran kualitas tanah.

\section{Bahan dan Metode}

\section{Tempat dan waktu penelitian}

Penelitian ini dilaksanakan di DAS Mikro Supiturung, Kabupaten Kediri, Jawa Timur. Tepatnya terletak di lereng bagian barat dari Gunung Kelud dengan luas total wilayah 1.911,37 ha. Analisis sifat fisika tanah dilakukan di Laboratorium Fisika Tanah Jurusan Tanah Fakultas Pertanian Universitas Brawijaya Malang. \Analisis sifat kimia tanah dilakukan di Laboratorium Uji Tanah Balai Pengkajian Teknologi Pertanian Jawa Timur. Penelitian dilaksanakan pada bulan Agustus 2020 - Maret 2021. Survei lapangan dilaksanakan pada bulan Agustus 2020. Analisis sifat fisika tanah dilaksanakan pada bulan Oktober 2020. Analisis sifat kimia tanah dilaksanakan pada bulan November 2020 - Januari 2021. Analisis data dan penyusunan laporan akhir dilaksanakan pada bulan Februari - Maret 2021.

\section{Alat dan bahan}

Alat yang digunakan adalah Seperangkat laptop ASUS A455LF, Software ArcGIS 10.3, Software Global Mapper, Software Microsoft Office 2019, Software SPSS 23.0, Pisau lapangan, kantong plastik, kertas label, ring sampel, bor tanah, peralatan analisis laboratorium fisika dan kimia tanah, kamera. Bahan yang digunakan adalah sampel tanah utuh dan sampel tanah terganggu, bahan analisis laboratorium fisika dan kimia tanah, Peta RBI Lembar Kediri, Ngancar dan Krisik 1:25.000, Peta Geologi Lembar Kediri 1:100.000, DEMNAS dan Citra Google Earth.

\section{Metode}

Penelitian ini dilaksanakan dengan menggunakan metode survei fisiografis melalui pendekatan analitik yang dipadukan dengan Sistem Informasi Geografis. Survei lapangan dilaksanakan berupa pengambilan sampel tanah utuh dan sampel tanah terganggu pada setiap satuan peta lahan untuk keperluan analisis sifat fisika dan kimia tanah. Pengunaan Sistem Informasi Geografis meliputi pembuatan peta dasar, pembuatan peta satuan peta lahan untuk menentukan titik pengamatan serta pembuatan peta indeks kualitas tanah dari hasil pembobotan dan penjumlahan indikator kualitas tanah. Terdapat 10 satuan peta lahan (SPL) dengan jumlah titik pengamatan per satuan peta lahan sebanyak 2 titik, sehingga terdapat 20 total titik pengamatan. Indikator kualitas tanah ditentukan berdasarkan kunci sifat tanah dengan metode Minumum Data Set (MDS), dengan indikator kualitas tanah dari sifat fisika tanah meliputi: tekstur, berat isi, porositas dan siifat kimia tanah meliputi: $\mathrm{pH}, \mathrm{P}$ tersedia, Kdd, $\mathrm{N}$ total, $\mathrm{C}$ 


\section{Jurnal Tanah dan Sumberdaya Lahan Vol 8 No 2: 527-537, 2021 e-ISSN:2549-9793, doi: 10.21776/ub.jts1.2021.008.2.23}

organik. Analisis sampel tanah di laboratorium dilakukan untuk penetapan: tekstur (Metode Pipet), berat isi (Ring Sample), porositas (Ring Sample), $\mathrm{pH}$ ((1:5), Elektrometri; $\mathrm{pH}$ Meter), P tersedia (Olsen; Spektrofotometer), Kdd $\left(\mathrm{NH}_{4-}\right.$ Ac $1 \mathrm{M}, \mathrm{pH}$ 7; AAS), $\mathrm{N}$ total (Kjedahl; Titrimetri) dan C organik (Walkley dan Black). Analisis indeks kualitas tanah dihitung berdasarkan data hasil analisis laboratorium terhadap indikator kualitas tanah yang dipilih, yaitu: tekstur, berat isi, porositas, $\mathrm{pH}, \mathrm{P}$ tersedia, Kdd, $\mathrm{N}$ total dan $\mathrm{C}$ organik. Menurut Partoyo (2005), langkah-langkah dalam menghitung indeks kualitas tanah adalah sebagai berikut: a. Indeks bobot diperoleh dengan mengalikan bobot fungsi tanah (bobot 1) dengan bobot media perakaran (bobot 2) serta dengan bobot kedalaman akar (bobot 3). Misalnya, indeks bobot untuk berat isi diperoleh dengan mengalikan 0,4 (bobot 1) dengan 0,33 (bobot 2) dengan 0,4 (bobot 3) dan hasilnya sama dengan 0,053 (Tabel 1).

b. Skor tersebut dihitung dengan membandingkan data observasi indikator tanah dengan fungsi evaluasi. Skor bernilai dengan rentang 0 (untuk kondisi buruk) sampai 1 (untuk kondisi baik). Skor tersebut dapat ditentukan dengan interpolasi atau persamaan linier berdasarkan rentang yang ditentukan dari data yang diperoleh. Fungsi persamaan linier yang digunakan adalah sebagai berikut:

$(Y)=(x-x 2) /(x 1-x 2)$

$(Y)=1-(x-x 2) /(x 1-x 2)$

Keterangan: Y (skor linier), $x$ (nilai sifat-sifat tanah), $\mathrm{x} 2$ (nilai batas atas), dan x1(nilai batas bawah).

Tabel 1. Modifikasi indikator, bobot dan batas-batas fungsi penilaian.

\begin{tabular}{|c|c|c|c|c|c|c|c|c|c|c|}
\hline \multirow{3}{*}{$\begin{array}{l}\text { Fungsi } \\
\text { tanah }\end{array}$} & \multirow{3}{*}{$\begin{array}{c}\text { Bobot } \\
1 \\
\end{array}$} & \multirow{3}{*}{$\begin{array}{c}\text { Indikator } \\
\text { tanah }\end{array}$} & \multirow[t]{3}{*}{ Satuan } & \multirow{3}{*}{$\begin{array}{c}\text { Bobot } \\
2 \\
\end{array}$} & \multirow{3}{*}{$\begin{array}{c}\text { Bobot } \\
3 \\
\end{array}$} & \multirow{3}{*}{$\begin{array}{c}\begin{array}{c}\text { Indeks } \\
\text { bobot }\end{array} \\
(1 \times 2 \times 3) \\
\end{array}$} & \multicolumn{4}{|c|}{ Fungsi penilaian } \\
\hline & & & & & & & \multicolumn{2}{|c|}{$\begin{array}{c}\text { Batas } \\
\text { bawah }\end{array}$} & \multicolumn{2}{|c|}{$\begin{array}{c}\text { Batas } \\
\text { atas }\end{array}$} \\
\hline & & & & & & & $\mathbf{x}_{1}$ & $\mathrm{y}_{2}$ & $\mathrm{x}_{1}$ & $\mathrm{y}_{2}$ \\
\hline \multirow{12}{*}{$\begin{array}{l}\text { Melestari } \\
\text { kan } \\
\text { aktivitas } \\
\text { biologi }\end{array}$} & \multirow{12}{*}{0,4} & $\begin{array}{l}\text { A. Media } \\
\text { perakaran } \\
\text { Kedalaman } \\
\text { perakaran }\end{array}$ & $\mathrm{cm}$ & 0,33 & 0,6 & 0,080 & 20 & 0 & 80 & 1 \\
\hline & & Berat isi & $\mathrm{g} \mathrm{cm}^{-3}$ & & 0,4 & 0,053 & 0,6 & 0 & 1,4 & 1 \\
\hline & & $\begin{array}{l}\text { B. } \\
\text { Kelengasan }\end{array}$ & & 0,33 & & & & & & \\
\hline & & Porositas & $\%$ & & 0,2 & 0,027 & 10 & 0 & 55 & 1 \\
\hline & & C organik & $\%$ & & 0,4 & 0,053 & 0,6 & 0 & 2 & 1 \\
\hline & & Debu + liat & $\%$ & & 0,4 & 0,053 & 0 & 0 & 100 & 1 \\
\hline & & C. Keharaan & & 0,33 & & & & & & \\
\hline & & $\mathrm{pH}$ & & & 0,1 & 0,013 & 4 & 0 & 8,2 & 1 \\
\hline & & P tersedia & ppm & & 0,2 & 0,027 & 4 & 0 & 10 & 1 \\
\hline & & Kdd & $\mathrm{cmol} \mathrm{kg}^{-1}$ & & 0,2 & 0,027 & 0,05 & 0 & 1 & 1 \\
\hline & & C organik & $\%$ & & 0,3 & 0,040 & 0,6 & 0 & 2 & 1 \\
\hline & & $\mathrm{N}$ total & $\%$ & & 0,2 & 0,027 & 0,25 & 0 & 2,5 & 1 \\
\hline \multirow{3}{*}{$\begin{array}{l}\text { Pengatura } \\
\mathrm{n} \text { dan } \\
\text { penyalura } \\
\mathrm{n} \text { air }\end{array}$} & \multirow{3}{*}{0,3} & Debu + liat & $\%$ & 0,6 & & 0,18 & 0 & 0 & 100 & 1 \\
\hline & & Porositas & $\%$ & 0,2 & & 0,06 & 10 & 0 & 55 & 1 \\
\hline & & Berat isi & $\mathrm{g} \mathrm{cm}^{-3}$ & 0,2 & & 0,06 & 0,6 & 0 & 1,4 & 1 \\
\hline \multirow{5}{*}{$\begin{array}{l}\text { Penyaring } \\
\text { dandan } \\
\text { penyangg } \\
\text { a }\end{array}$} & \multirow{5}{*}{0,3} & Debu + liat & $\%$ & 0,6 & & 0,18 & 0 & 0 & 100 & 1 \\
\hline & & Porositas & $\%$ & 0,1 & & 0,03 & 10 & 0 & 55 & 1 \\
\hline & & $\begin{array}{l}\text { Proses } \\
\text { mikrobiologi }\end{array}$ & & 0,3 & & & & & & \\
\hline & & C organik & $\%$ & & 0,5 & 0,045 & 0,6 & 0 & 2 & 1 \\
\hline & & $\mathrm{N}$ total & $\%$ & & 0,5 & 0,045 & 0,15 & 0 & 2,5 & 1 \\
\hline Total & & & & & & 1,00 & & & & \\
\hline
\end{tabular}

Sumber: Partoyo (2005). 


\section{Jurnal Tanah dan Sumberdaya Lahan Vol 8 No 2: 527-537, 2021 e-ISSN:2549-9793, doi: 10.21776/ub.jts1.2021.008.2.23}

c. Indeks Kualitas Tanah diperoleh dengan cara mengalikan indeks bobot dengan skor dari indikator terpilih. Penilaian kualitas tanah menggunakan persamaan indeks kualitas tanah (Liu et al., 2014) yaitu:

$\mathrm{IKT}=\mathrm{Wi} \times \mathrm{Si}$.

Keterangan: IKT (indeks kualitas tanah) Si (skor indikator terpilih), Wi (indeks bobot).

Data Indeks Kualitas Tanah (IKT) yang didapatkan dari pembobotan dan penjumlahan dibandingkan dengan kriteria kualitas tanah berdasarkan nilai indeks kualitas tanah yang terdiri dari lima kelas (Tabel 2), kemudian selanjutnya dilakukan pembuatan peta sebaran kualitas tanah di lokasi penelitian.

Tabel 2. Kriteria kualitas tanah berdasarkan nilai indeks kualitas tanah (IKT).

\begin{tabular}{ccc}
\hline No & Kelas Nilai & $\begin{array}{c}\text { Kriteria Kualitas } \\
\text { Tanah }\end{array}$ \\
\hline 1. & $0,80-1,00$ & Sangat baik (SB) \\
2. & $0,60-0,79$ & Baik (B) \\
3. & $0,40,0,59$ & Sedang (S) \\
4. & $0,20-0,39$ & Rendah (R) \\
5. & $0,00-0,19$ & Sangat rendah (SR) \\
\hline
\end{tabular}

Sumber: Partoyo (2005).

\section{Hasil dan Pembahasan}

\section{Kondisi umum wilayah}

Lokasi penelitian berada di DAS Mikro Supiturung, Kabupaten Kediri, Jawa Timur yang melewati empat desa yaitu Desa Sepawon, Sugihwaras, Plosokidul dan Jarak dengan luas 1.911,37 ha. Secara astronomis, daerah penelitian berada antara $9.123 .000-9.129 .000 \mathrm{~m}$ $\mathrm{S}$ dan $624.000-640.000 \mathrm{~m} \mathrm{E}$ dengan sistem proyeksi Universal Transverse Mercator pada zona 49 selatan. Secara geografis daerah penelitian berada pada lereng barat Gunung Kelud yang berbatasan pada bagian barat dengan Kecamatan Gurah, bagian utara dengan Kecamatan Pare, bagian Timur dengan Kecamatan puncu dan bagian selatan dengan Kota Blitar. Kondisi geologi tersusun atas tiga formasi geologi yaitu Batuan gunung api kelud tua (Qpvk), Batuan gunung api kelud muda (Qvk) dan Endapan lahar (Qvlh). Ketinggian tempat berkisar antara $200-1.200 \mathrm{~m}$ di atas permukaan laut (mdpl) dengan relief datar hingga bergunung dan kemiringan lereng 3$40 \%$. Jumlah curah hujan tahunan rata-rata $1.797,5 \mathrm{~mm}$ tahun $^{-1}$ dengan rata-rata suhu minimum $23,8^{\circ} \mathrm{C}$ dan maksimum $30,7^{\circ} \mathrm{C}$. Jenis tanah didominasi oleh tanah Inceptisols dan Entisols. Penggunaan lahan berupa hutan alami, hutan produksi, semak belukar, tegalan, sawah dan permukiman. Jenis pengunaan lahan terbesar adalah tegalan mencapai 1.155,25 hektar atau sekitar $60,44 \%$ dari luas total wilayah, kemudian jenis pengunaan lahan terkecil adalah semak beluar sebesar 25,76 hektar atau 1,35\% dari luas total wilayah dengan komoditas dominan berupa nanas, tebu dan kakao. Peta titik pengamatan disajikan pada (Gambar 1).

\section{Sebaran indeks kualitas tanah}

Hasil pembobotan dan penjumlahan indeks kualitas tanah menunjukkan bahwa sebaran indeks kualitas tanah pada lokasi penelitian dominan berada pada kategori rendah yaitu dengan rentang nilai $0,20-0,39$. Hanya 1 SPL yaitu pada SPL 2 yang mempunyai nilai IKT 0,43 termasuk dalam kategori sedang yaitu dengan rentang nilai $0,40-0,59$ (Tabel 3). Rendahnya nilai IKT pada hampir semua SPL karena oleh indikator tanah yang memiliki nilai rendah seperti tekstur tanah yang dominan pasir berat, $\mathrm{pH}$ yang tidak sesuai dan kandungan hara dalam tanah yang juga rendah meliputi $\mathrm{C}$ organic, $\mathrm{P}$ tersedia, Kdd dan juga $\mathrm{N}$ total tanah. Tekstur tanah pada daerah penelitian dominan berpasir yang memiliki fraksi $>70 \%$ pasir dan termasuk dalam kelas lempung berpasir. Menurut Arifin (2011), tekstur tanah mempunyai peranan dalam mempengaruhi sifat fisik dan kimia tanah, terutama hubungannya dalam kapasitas menahan air dan unsur hara. Rukmi et al. (2017) menyatakan bahwa tanah dengan tekstur lempung berpasir memiliki pori makro lebih besar daripada pori mikro, sehingga kapasitas menahan air dan unsur haranya menjadi kecil tetapi sangat efisien dalam hal sirkulasi air dan udara. Sejumlah unsur hara memiliki sifat yang mudah larut pada tanah yang mengalami erosi. Kondisi tersebut dapat dilihat pada satuan peta lahan yang dilewati oleh aliran lahar memiliki permukaan tanah yang lebih dinamis jika dibandingkan dengan satuan peta lahan lainnya. 


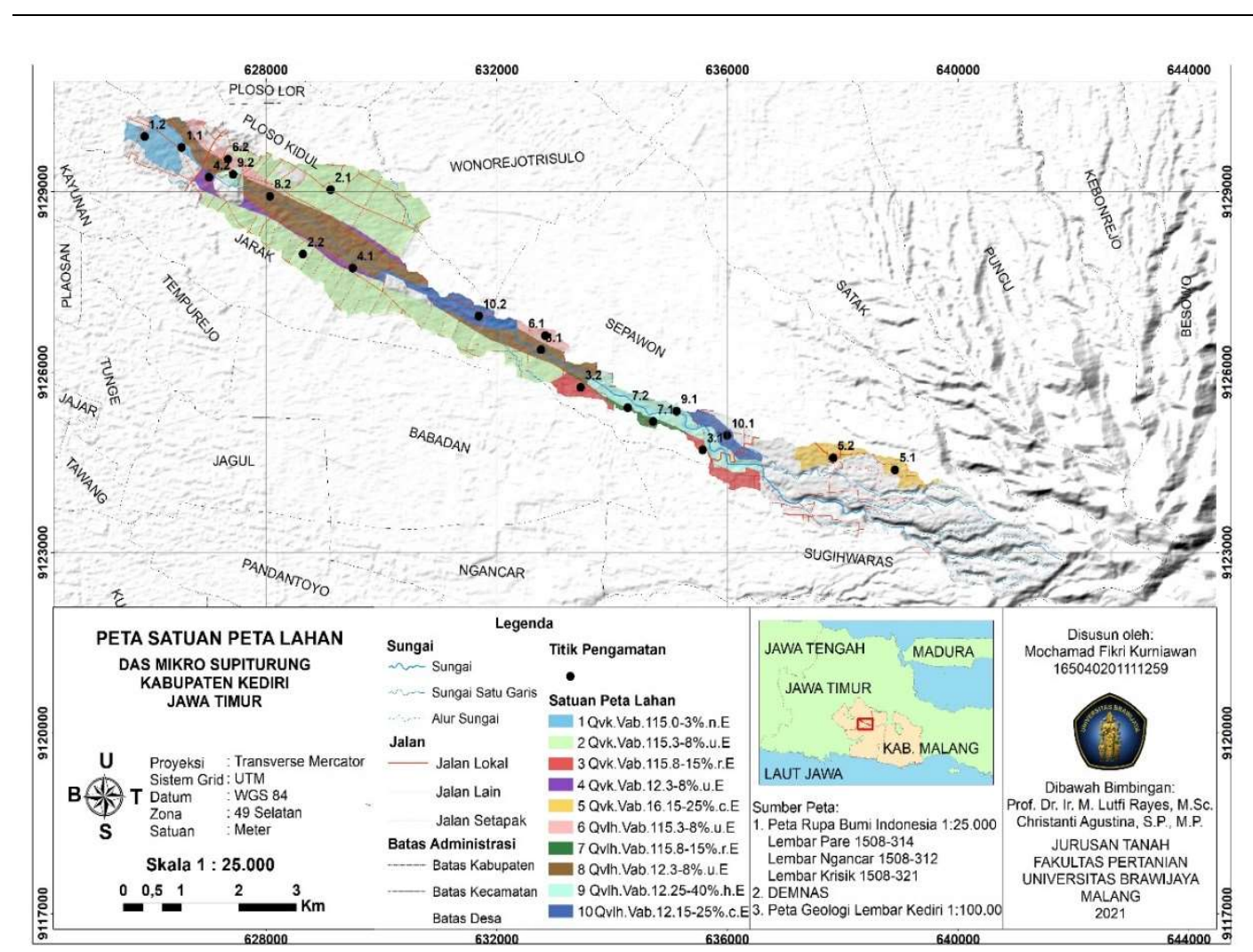

Gambar 1. Peta satuan peta lahan lokasi penelitian.

Keterangan : Qvk (Batuan gunung api kelud muda), Qvlh (Endapan lahar), Vab.115 (Sub landform lereng volkan bawah), Vab.12 (Sub landform aliran lahar), Vab.16 (Sub landform lungur volkan), n (Relief datar), u (Relief berombak), r (Relief bergelombang), c (Relief berbukit kecil), h (Relief berbukit) dan E (Penggunaan lahan tegalan).

Air yang mengalir dari hulu ke hilir akan menyebabkan run off sehingga kandungan unsur hara yang ada di tanah ikut terangkut. Namun meskipun demikian satuan peta lahan yang dilewati oleh aliran lahar juga akan tetap tersuplai berbagai mineral dari material vulkanik yang berasal dari Gunung Kelud. Pada SPL 6, yaitu pada titik pengamatan 1 memiliki indeks kualitas tanah sebesar 0,66 (kategori baik). Nilai IKT yang tergolong baik tersebut karena indikator tanah yang memiliki nilai baik juga, Berdasarkan hasil analisa tekstur tanah pada lokasi tersebut memiliki fraksi pasir total lebih sedikit dibandingkan lokasi lainnya yaitu sebesar $20 \%$, sehingga jika dikelaskan masuk dalam kelas lempung berdebu. Tanah dengan tekstur lempung berdebu memiliki ruang pori lebih banyak sehingga memiliki porositas yang besar. Hal ini sejalan dengan Rukmi et al. (2017) bahwa tanah dengan tekstur lempung berdebu tersusun dari pori-pori mikro sehingga kemampuan menahan air dan unsur haranya lebih baik dibandingkan tanah dengan lempung berpasir yang memiliki lebih banyak pori makro. Titik pengamatan 2 pada SPL 6 memiliki nilai indeks kualitas tanah sebesar 0,37 (kategori rendah), sehingga keseluruhan SPL 6 indeks kualitas tanahnya termasuk dalam kategori rendah karena pada titik pengamatan 2 memiliki kategori indeks kualitas tanah yang rendah sehingga dipilih kelas terberatnya untuk ke depannya dapat dilakukan usaha perbaikan. Peta nilai indeks kualitas tanah disajikan pada (Gambar 2).

\section{Hubungan antara indikator kualitas tanah dengan indeks kualitas tanah}

Hasil uji korelasi antara indikator-indikator kualitas tanah dari sifat fisik dan kimia dengan indeks kualitas tanah mempunyai nilai korelasi tinggi yaitu dengan nilai $r=\geq 0,5$. 
Jurnal Tanah dan Sumberdaya Lahan Vol 8 No 2: 527-537, 2021

e-ISSN:2549-9793, doi: 10.21776/ub.jts1.2021.008.2.23

Tabel 3. Sebaran nilai indeks kualitas tanah.

\begin{tabular}{|c|c|c|c|c|c|c|}
\hline \multirow[t]{2}{*}{ SPL } & \multirow{2}{*}{$\begin{array}{c}\text { Titik } \\
\text { Pengamatan }\end{array}$} & \multicolumn{3}{|c|}{ Fungsi Tanah } & \multirow{2}{*}{$\begin{array}{l}\text { Kelas } \\
\text { Nilai }\end{array}$} & \multirow{2}{*}{$\begin{array}{c}\text { Kriteria } \\
\text { Kualitas } \\
\text { Tanah }\end{array}$} \\
\hline & & $\begin{array}{l}\text { Melestarikan } \\
\text { aktivitas biologi }\end{array}$ & $\begin{array}{c}\text { Pengaturan dan } \\
\text { penyaluran air }\end{array}$ & $\begin{array}{c}\text { Penyaring } \\
\text { dan } \\
\text { penyangga }\end{array}$ & & \\
\hline \multirow{2}{*}{1} & $1.1 \mathrm{LB}$ & 0,14 & 0,11 & 0,10 & 0,35 & Rendah \\
\hline & $1.2 \mathrm{LB}$ & 0,15 & 0,13 & 0,10 & 0,38 & Rendah \\
\hline \multirow{2}{*}{2} & $2.1 \mathrm{LB}$ & 0,20 & 0,11 & 0,12 & 0,43 & Sedang \\
\hline & 2.2 LT & 0,20 & 0,11 & 0,12 & 0,43 & Sedang \\
\hline \multirow{2}{*}{3} & $3.1 \mathrm{LT}$ & 0,19 & 0,09 & 0,10 & 0,38 & Rendah \\
\hline & $3.2 \mathrm{LT}$ & 0,12 & 0,11 & 0,05 & 0,28 & Rendah \\
\hline \multirow{2}{*}{4} & 4.1 LB & 0,13 & 0,12 & 0,07 & 0,32 & Rendah \\
\hline & 4.2 LB & 0,17 & 0,10 & 0,10 & 0,37 & Rendah \\
\hline \multirow{2}{*}{5} & $5.1 \mathrm{LA}$ & 0,17 & 0,09 & 0,08 & 0,34 & Rendah \\
\hline & $5.2 \mathrm{LA}$ & 0,22 & 0,10 & 0,13 & 0,45 & Sedang \\
\hline \multirow{2}{*}{6} & 6.1 LT & 0,22 & 0,20 & 0,24 & 0,66 & Baik \\
\hline & $6.2 \mathrm{LB}$ & 0,17 & 0,10 & 0,10 & 0,37 & Rendah \\
\hline \multirow{2}{*}{7} & 7.1 LT & 0,12 & 0,10 & 0,10 & 0,32 & Rendah \\
\hline & 7.2 LT & 0,12 & 0,11 & 0,10 & 0,33 & Rendah \\
\hline \multirow{2}{*}{8} & 8.1 LT & 0,12 & 0,12 & 0,09 & 0,33 & Rendah \\
\hline & $8.2 \mathrm{LB}$ & 0,12 & 0,09 & 0,05 & 0,26 & Rendah \\
\hline \multirow{2}{*}{9} & $9.1 \mathrm{LT}$ & 0,18 & 0,10 & 0,09 & 0,37 & Rendah \\
\hline & $9.2 \mathrm{LB}$ & 0,16 & 0,11 & 0,09 & 0,36 & Rendah \\
\hline \multirow{2}{*}{10} & $10.1 \mathrm{LT}$ & 0,18 & 0,10 & 0,10 & 0,38 & Rendah \\
\hline & $10.2 \mathrm{LT}$ & 0,12 & 0,12 & 0,13 & 0,37 & Rendah \\
\hline
\end{tabular}

*Keterangan : LA (Lereng Atas), LT (Lereng Tengah), LB (Lereng Bawah).

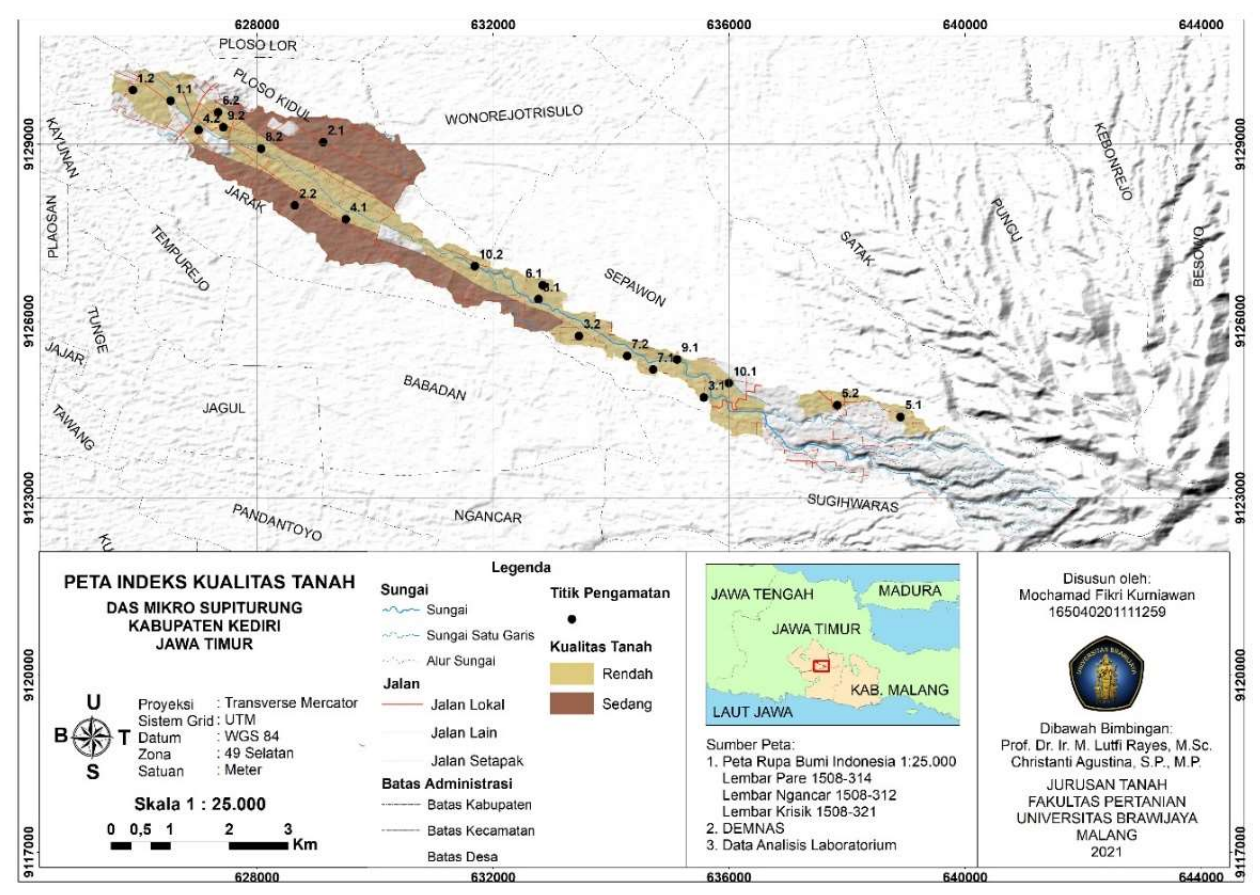

Gambar 2. Peta indeks kualitas tanah lokasi penelitian. 


\section{Jurnal Tanah dan Sumberdaya Lahan Vol 8 No 2: 527-537, 2021 \\ e-ISSN:2549-9793, doi: 10.21776/ub.jts1.2021.008.2.23}

Terdapat 4 indikator yang mempunyai nilai determinasi paling tinggi yang memberikan pengaruh nyata terhadap indeks kualitas tanah. Indikator-indikator tersebut yaitu persentase pasir dengan nilai $\mathrm{R}^{2}=0,6954$, persentase debu dengan nilai $\mathrm{R}^{2}=0,7115, \mathrm{~N}$ total dengan nilai $\mathrm{R} 2=0,5588$ dan $\mathrm{C}$ organik dengan nilai $\mathrm{R}^{2}=0,5635$. Indikator lainnya mempunyai nilai korelasi kecil yaitu dengan nilai $\mathrm{r}=\leq 0,5$ seperti berat isi dengan nilai $\mathrm{R} 2=0,1564$, porositas dengan nilai $\mathrm{R}^{2}=0,0192$, persentase liat dengan nilai $\mathrm{R}^{2}=0,0119$, $\mathrm{pH}$ dengan nilai $\mathrm{R} 2=0,1096$, Kdd dengan nilai R2=0,0024, dan $\mathrm{P}$ tersedia dengan nilai $\mathrm{R}^{2}=0,032$ sehingga tidak memberikan pengaruh terhadap indeks kualitas tanah. Kemudian berdasarkan analisis regresi terdapat hubungan dari empat indikator dengan indeks kualitas tanah, dimana hubungan yang terjadi adalah sebagai berikut :

\section{Hubungan tekstur dengan indeks kualitas tanah}

Persentase pasir merupakan salah satu indikator tanah yang mempengaruhi indeks kualitas tanah secara signifikan $(p<0.01)$, dengan nilai koefisien korelasi -0,834 yang berarti terdapat hubungan yang kuat antara kandungan fraksi pasir dengan indeks kualitas tanah. Berdasarkan persamaan linier (Gambar 3), nilai $\mathrm{R}^{2}=0,6954$ menunjukkan bahwa kandungan fraksi pasir mempengaruhi indeks kualitas tanah sebesar
$69,5 \%$, dimana hubungan yang terjadi berbanding terbalik yaitu semakin besar nilai fraksi pasir maka akan menurunkan nilai indeks kualitas tanah. Persentase debu juga mempengaruhi indeks kualitas tanah secara signifikan $(\mathrm{p}<0.01)$, dengan nilai koefisien korelasi 0,844 yang berarti terdapat hubungan yang saling mempengaruhi antara kandungan fraksi debu dengan indeks kualitas tanah. Berdasarkan persamaan linier (Gambar 4), nilai $\mathrm{R}^{2}=0,7115$ menunjukkan bahwa kandungan fraksi debu mempengaruhi indeks kualitas tanah sebesar $71 \%$, dimana hubungan yang terjadi berbanding lurus yaitu semakin besar nilai fraksi debu maka akan meningkatkan nilai indeks kualitas tanah.

Dapat disimpulkan bawah kandungan fraksi debu di dalam tekstur tanah sangat mempengaruhi kualitas suatu tanah. Hal itu karena fraksi debu merupakan bagian dari partikel tanah yang paling stabil dan tahan terhadap erosi. Erosi akan membuat hilangnya sejumlah lapisan tanah yang mengandung unsur hara, sehingga tanah akan kehilangan sejumlah unsur hara. Hal ini sesuai dengan Arifin et al. (2018) bahwa tekstur tanah yang paling peka terhadap erosi adalah pasir sangat halus dan debu. Oleh sebab itu semakin tinggi kandungan debu dalam tanah akan menjaga kualitas dari tanah tersebut.

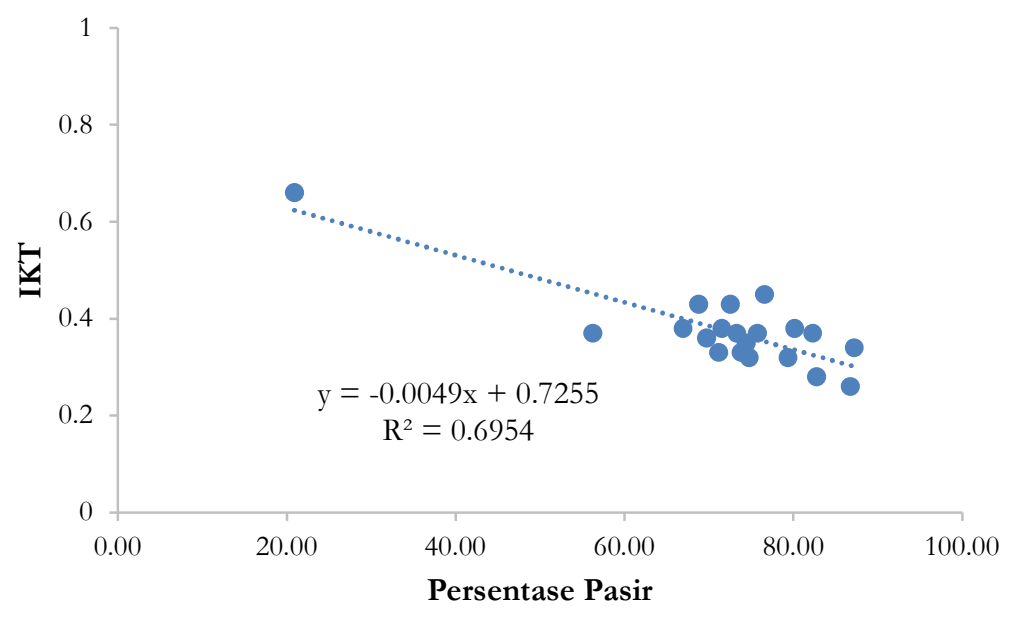

Gambar 3. Grafik hubungan fraksi pasir dengan indeks kualitas tanah. 


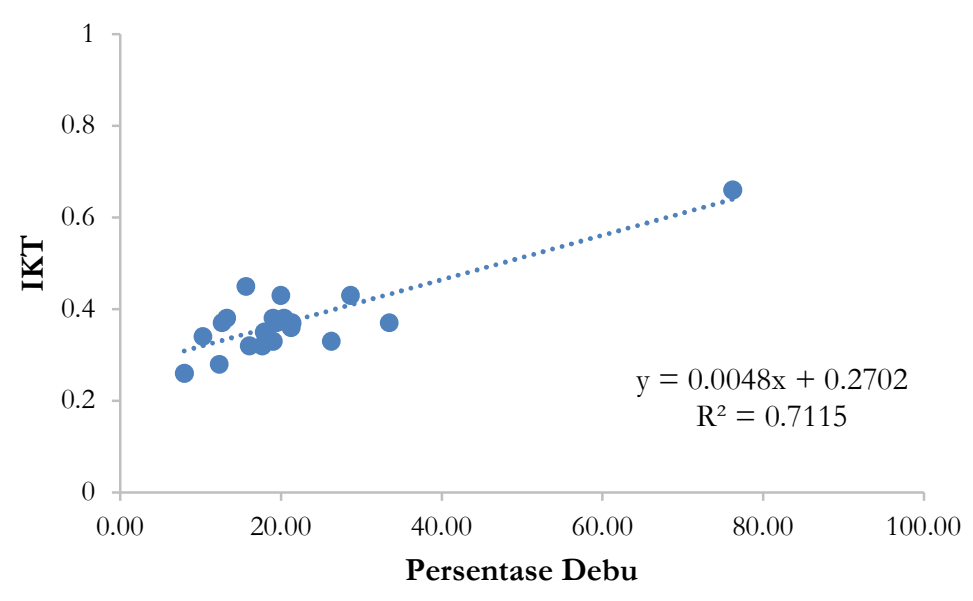

Gambar 4. Grafik hubungan fraksi debu dengan indeks kualitas tanah.

\section{Hubungan $N$ total dengan indeks kualitas tanah}

Gambar 5 menunjukkan bahwa indikator N total tanah mempunyai hubungan yang signifikan dengan indeks kualitas tanah $(\mathrm{p}<0.01)$, dengan nilai koefisien korelasi 0,748 . Koefisien korelasi yang bernilai positif menunjukkan bahwa hubungan antara indikator $\mathrm{N}$ total tanah terhadap indeks kualitas tanah berbanding lurus. Nilai $\mathrm{R}^{2}=0,5588$ menunjukkan bahwa kandungan $\mathrm{N}$ total mempengaruhi indeks kualitas tanah sebesar $55,8 \%$ dan sisanya dipengaruhi oleh faktor lain. Hubungan yang terjadi menunjukkan bahwa garis kecenderungan indeks kualitas tanah meningkat seiring dengan kenaikan $\mathrm{N}$ total yang berarti indikator $\mathrm{N}$ total memberikan pengaruh yang signifikan terhadap IKT. Kandungan N dalam tanah ditentukan oleh tekstur tanah. Jenis tanah dengan tekstur halus memiliki kadar $\mathrm{N}$ total tanah lebih tinggi (Barus et al., 2013). Faktor lain yang menjadi penyebab banyaknya $\mathrm{N}$ dalam tanah tergantung dari keadaan lingkungannya seperti iklim dan jenis vegetasi. Vegetasi yang tumbuh di atas tanah dan kecepatan dekomposisinya merupakan faktor penyebab perubahan terhadap kandungan $\mathrm{N}$ dalam tanah (Supangat et al., 2013). Oleh sebab itu, $\mathrm{N}$ total menjadi indikator dalam kualitas tanah karena merupakan unsur hara makro yang dibutuhkan oleh tanah dan pertumbuhan tanaman.

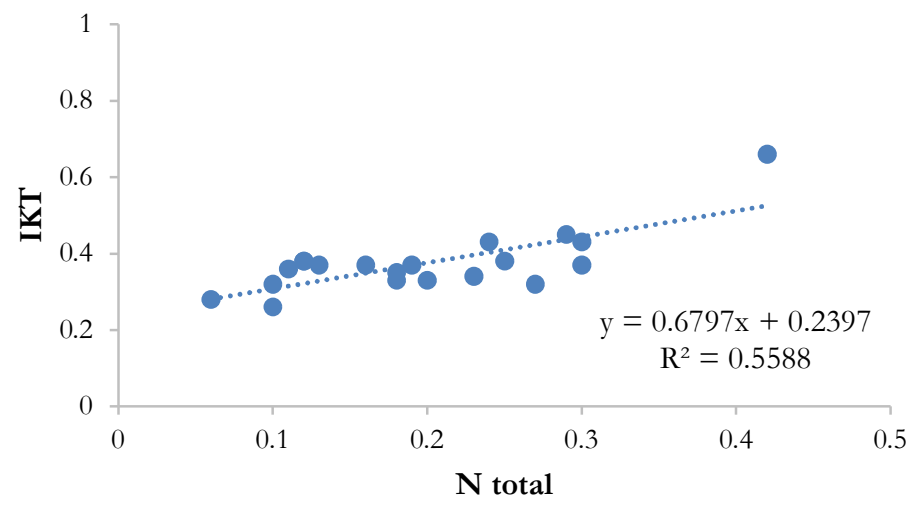

Gambar 5. Grafik hubungan N total tanah dengan indeks kualitas tanah. 


\section{Jurnal Tanah dan Sumberdaya Lahan Vol 8 No 2: 527-537, 2021}

e-ISSN:2549-9793, doi: 10.21776/ub.jts1.2021.008.2.23

\section{Hubungan C organik dengan indeks kualitas tanah}

Gambar 6 menunjukkan bahwa indikator C organik tanah mempengaruhi indeks kualitas tanah secara signifikan $(\mathrm{p}<0.01)$, dengan nilai koefisien korelasi 0,751 . Koefisien korelasi yang bernilai positif menunjukkan bahwa hubungan antara indikator $\mathrm{C}$ organik terhadap indeks kualitas tanah berbanding lurus. Nilai $\mathrm{R}^{2}=0,5635$ menunjukkan bahwa kandungan $\mathrm{C}$ organik mempengaruhi indeks kualitas tanah sebesar $56,3 \%$ dan sisanya dipengaruhi oleh faktor lain. Hubungan yang terjadi menunjukkan bahwa garis kecenderungan indeks kualitas tanah meningkat seiring dengan kenaikan C organik. Maka, berdasarkan persamaan regresi tersebut tersebut dapat disimpulkan bahwa setiap kenaikan 1\% C organik tanah akan menaikan indeks kualitas tanah sebesar 0,1 satuan satuan yang berarti indikator $\mathrm{C}$ organik tanah memberikan pengaruh yang signifikan terhadap indeks kualitas tanah. Rendahnya kandungan $\mathrm{C}$ organik dalam tanah karena kurang masukan bahan organik yang diberikan pada tanah. Bahan organik berfungsi dalam perbaikan sifat-sifat tanah secara keseluruhan meliputi sifat fisika, kimia dan biologi tanah. Peranan bahan organik dapat memperbaiki struktur tanah, meningkatkan kapasitas tanah dalam menahan air, meningkatkan status keharaan serta meningkatkan kapasitas tukar kation (Kusumandaru et al., 2015). Sehingga bahan organik menjadi indikator yang cukup penting dalam kualitas tanah.

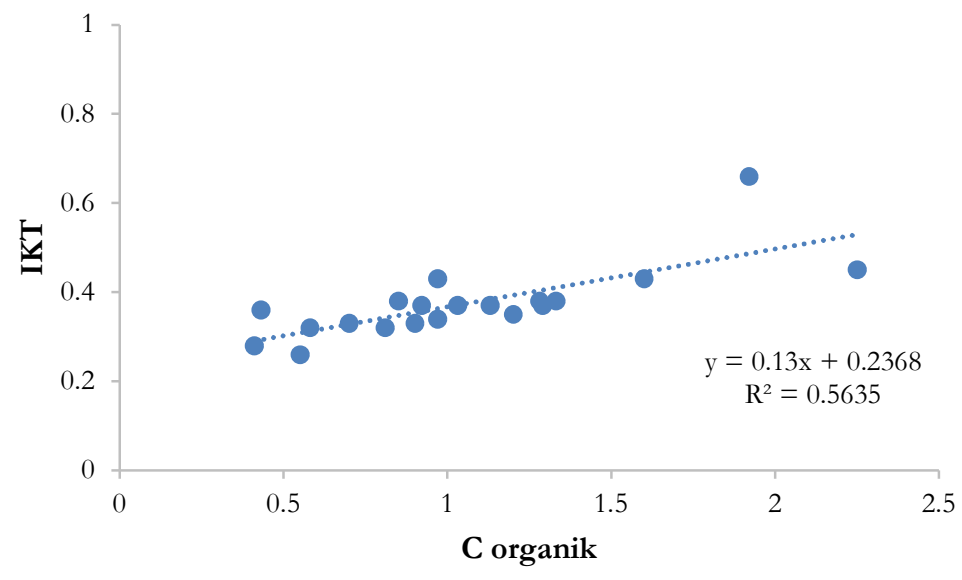

Gambar 6. Grafik hubungan C organik tanah dengan indeks kualitas tanah.

\section{Indikator kualitas tanah yang paling berpengaruh terhadap indeks kualitas tanah}

Indeks kualitas tanah dipengaruhi oleh beberapa indikator tanah. Hasil analisis menunjukkan bahwa terdapat dua indikator yang paling berpengaruh terhadap indeks kualitas tanah yaitu persentase debu dan $\mathrm{C}$ organik. Hasil analisis tersebut didapatkan melalui uji regresi berganda dengan metode stepwise. Berdasarkan koefisien hasil uji regresi berganda dengan metode (stepwise) diperoleh persamaan terbaik yaitu:
$Y=0,204+0,004 X 1+0,086 X 2$

dimana:

$\mathrm{Y}=$ Indeks Kualitas Tanah

$\mathrm{X} 1=$ Persentase Debu

$\mathrm{X} 2=\mathrm{C}$ organik

tanah kemudian diikuti oleh indikator lainnya yaitu C organik berdasarkan output Model Summay nilai R (koefisien korelasi) sebesar 0.958, yang berarti variabel dependent dan independent dapat dikategorikan memiliki hubungan linear yang sangat kuat. Kemudian berdasarkan angka 


\section{Jurnal Tanah dan Sumberdaya Lahan Vol 8 No 2: 527-537, 2021 e-ISSN:2549-9793, doi: 10.21776/ub.jts1.2021.008.2.23}

Adjusted R Square menunjukkan sebesar 0.91 yang berarti bahwa persentase debu dan $\mathrm{C}$ organik berpengaruh sebesar $91 \%$ terhadap Indeks Kualitas tanah sedangkan sisanya sebesar $9 \%$ dipengaruhi oleh variabel atau faktor yang lain di luar penelitian. Indikator tekstur tanah memberikan pengaruh dalam meningkatkan kualitas tanah. Tekstur tanah berhubungan dengan permeabilitas, kemampuan memegang air, aerasi, erosi, kapasitas tukar kation serta kesuburan tanah (Juarti, 2016). Tanah yang didominasi fraksi pasir mempunyai luas permukaan yang kecil sehingga kemampuan menahan air dan unsur haranya rendah. Tanah yang didominasi oleh fraksi debu memiliki luas permukaan yang lebih besar dari pasir sehingga pembebasan unsur hara untuk diserap oleh akar tanaman menjadi lebih besar dan aktif dalam memegang air untuk tanaman (Juarti, 2016). Keberadaan C organik memiliki pengaruh yang cukup besar dalam memperbaiki sifat fisika, kimia dan biologi tanah. Kusumandaru et al. (2015) mengemukakan bahwa kadar C organik dalam tanah dapat meningkatkan ketersediaan hara di tanah, mengurangi tingkat kepadatan tanah, memperbaiki struktur tanah, meningkatkan kemampuan tanah dalam mempertahankan air serta meningkatkan kapasitas tukar kation tanah.

\section{Kesimpulan}

Hasil perhitungan indeks kualitas tanah menunjukkan bahwa kualitas tanah pada lokasi penelitian termasuk ke dalam kategori rendah karena memiliki nilai IKT pada rentang 0,20 0,39 . Terdapat empat indikator yang memberikan pengaruh nyata terhadap indeks kualitas tanah yaitu persentase pasir berpengaruh sebesar $69,5 \%$, persentase debu berpengaruh sebesar $71 \%, \mathrm{~N}$ total berpengaruh sebesar $55,8 \%$ dan $\mathrm{C}$ organik berpengaruh sebesar 56,3\%. Hasil uji regresi berganda (stepwise), menunjukkan nilai $\mathrm{R}$ sebesar 0.958, yang berarti variabel dependent dan independent memiliki hubungan linear yang sangat kuat. Berdasarkan angka Adjusted $\mathrm{R}$ Square menunjukkan sebesar 0.91 yang berarti bahwa persentase debu dan $\mathrm{C}$ organik berpengaruh sebesar 91\% terhadap Indeks Kualitas Tanah sedangkan sisanya sebesar $9 \%$ dipengaruhi oleh variabel atau faktor yang lain diluar penelitian.

\section{Ucapan Terima Kasih}

Penulis mengucapkan terimakasih kepada teknisi Laboratorium Fisika Tanah, Jurusan Tanah, Fakultas Pertanian, Universitas Brawijaya khususnya untuk Bapak Ngadirin yang selalu senantiasa membimbing dan membantu dalam analisis laboratorium serta teknisi Laboratorium Uji Tanah Balai Pengkajian Teknologi Pertanian Jawa Timur atas bantuannya dalam analisis sampel tanah.

\section{Daftar Pustaka}

Arifin, M., Putri, N.D., Sandrawati, A. dan Harryanto, R. 2018. Pengaruh posisi lereng terhadap sifat fisika dan kimia tanah pada Inceptisols di Jatinangor. Soilrens Jurnal Ilmiah Lingkungan Tanah Pertanian 16(2): 37-44.

Arifin, Z. 2011. Analisis indeks kualitas tanah Entisols pada berbagai penggunaan lahan yang berbeda. Agroteksos 21(1): 47-54.

Barus, N., Damanik, M.M. dan Supriadi. 2013. Ketersediaan nitrogen akibat pemberian berbagai jenis kompos pada tiga jenis tanah dan efeknya terhadap pertumbuhan tanaman jagung (Zea mays L.). Jurnal Online Agroekoteknologi 1(3): 711724.

Dong, C.Y., Yan, W.H., Min, Z.J., Lu, X., Shu, Z.B., Chun, Z.Y. and Qin, C.X. 2013. Minimum data set for assessing soil quality in farmland of Northeast China. Pedosphere 23(5): 564-576.

Juarti. 2016. Analisis kualitas tanah Andisol pada berbagai penggunaan lahan di Desa Sumber Brantas, Kota Batu. Jurnal Pendidikan Geografi 21(2): 58-71.

Kusumandaru, W., Hermiyanto, B. dan Winarso, S. 2015. Analisis indeks kualitas tanah di lahan pertanian tembakau Kasturi. Berkala Ilmiah Pertanian 2(4): 132-140.

Liu, Z, Zhou, W., Shen, J., Li, S.T., Liang, G., Wang, X., Sun, J. and Ai, C. 2014. Soil quality assessment of acid sulfate paddy soil with different productivities in Guangdong Province, China. Journal of Integrative Agriculture 13(1): 177-186.

Minarsih, S. Dan Hanudin, E. 2020. Kualitas Tanah pada Beberapa Tipe Penggunaan Lahan. Prosiding Seminar Nasional Pertanian Peternakan Terpadu 3. Universitas Muhammadiyah Purworejo. 14 Maret 2020.

Padmawati, N.A., Arthagama, I.M. dan Susila, K.D. 2017. Evaluasi kualitas tanah di lahan sawah Simantri dan Non Simantri di Subak Riang Desa Riang Gede. Agroekoteknologi Tropika 6(2): 185-193.

Partoyo. 2005. Analisis kualitas tanah pertanian di lahan pasir pantai Samas Yogyakarta. Jurnal Imu Pertanian 12 (2): 140-151. 


\section{Jurnal Tanah dan Sumberdaya Lahan Vol 8 No 2: 527-537, 2021 \\ e-ISSN:2549-9793, doi: 10.21776/ub.jts1.2021.008.2.23}

Rahmanipour, F., Arzaioli, R., Bahrami, H.A. and Fereidouni, Z. 2014. Assesment of soil quality in agricultural lands of Qazvin Province, Iran. Journal Ecological Indicator 40: 19-26.

Rukmi, Bratawinata, A.A., Pitopang, R. dan Matius, P. 2017. Sifat fisik dan kimia tanah pada berbagai ketinggian tempat di habitat eboni (Diospyros celebica Bakh.) DAS Sausu Sulawesi Tengah. Warta Rimba 5 (1): 28-36.

Supangat, A.B., Supriyo, H., Sudira, P. dan Poedjirahajoe, E. 2013. Status kesuburan tanah di bawah tegakan Eucalyptus pellita F. Mueii: Studi Kasus di HPHTI PT. Arara Abadi, Riau. Manusia dan Lingkungan 20(1): 22-34.
Tewu, R.W., Theffie, K.L dan Pioh, D.D. 2016. Kajian sifat fisik dan kimia tanah pada tanah berpasir di Desa Noongan Kecamatan Langowan Barat. Jurnal Agroekoteknologi 7(2): 74-81.

Wander, M.M., Walter, G.L., Nissen, T.M., Billero, G.A., Andrews, S. S. and Cavanaught-Grant, D.A. 2002. Soil quality: science and process. Agronomy Journal 94: 23-32. 